\title{
Review
}

\section{Anticancer Natural Products: A Review}

\author{
Ranwa A. Elrayess, PhD; Heba N. Gad El-Hak, PhD* \\ Department of Zoology, Suez Canal University, Ismailia, Egypt \\ *Corresponding author \\ Heba N. Gad El-Hak, PhD \\ Department of Zoology, Faculty of Science, Suez Canal University, Ismailia, Egypt; E-mail: heba nageh@hotmail.com
}

\section{Article information}

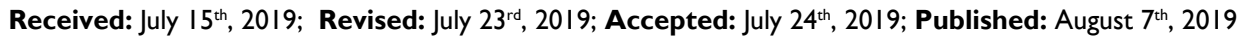

\section{Cite this article}

Elrayess RA, El-Hak HNG. Anticancer natural products:A Review. Cancer Stud Mol Med Open J. 20I9; 5(I): II-22. doi: I0.I7I40/CSMMOJ-5-I27

\section{ABSTRACT}

Historically, natural products played a forceful role in human treatment ailments. Nowadays, natural products include a large part of current pharmaceutical agents, mostly in the field of cancer therapy. The main aim of this review is to provide a comprehensive summary of the most known natural product used as anticancer globally, including various other natural products. Many of these natural product appears to act through an anticancer mechanism. Overall, natural product research is a vigorous tool to discover novel biologically active components with unique mechanisms of action. Given the diversity of nature, it is sensible to indicate that chemical leads can be produced that are able to interact with most therapeutic targets. This review creates a solid foundation for further study these natural products with additional research and study.

\section{Keywords}

Anticancer; Natural product; Plant compounds; Marine flora; Microorganisms; Venom.

\section{INTRODUCTION}

$\mathrm{C}$ ancer is a serous global health problem responsible for millions of deaths all over the world. It is responsible for approximately 7.6 million deaths worldwide, which is expected to increase to 13.1 million by $2030 .{ }^{1}$ Despite the progress in the field of cancer research, still there is a need to discover and develop anti-cancer therapeutic agents. Since long it has been recognized that, natural products represent the richest source of high chemical diversity, providing the basis for identification of novel scaffold structures that serves as starting points for rational drug design. ${ }^{1}$ This can be one of the reasons that efforts have been directed to discover promising cancer therapeutic agents from natural sources. Over the years, many natural product-based drugs have been introduced in the market. ${ }^{2}$ According to a recent review, $49 \%$ of drugs were either natural products or their derivatives that are used in cancer treatment. ${ }^{3}$ Moreover, between the year 2005 and 2010, nineteen natural product-based drugs have been approved, among which seven have been classified as natural product, ten as semi-synthetic natural product and two as natural product-derived drugs. ${ }^{4}$ Of these, five drugs, everolimus, temsirolimus, ixabepilone, trabectedin and romidepsin, have been developed in the feild of oncology from 2007 to 2009 .
Natural products comprise any substance produced by life organism. Mostly, these substances are of small molecular weight $(<3,000$ Daltons) and of considerable structural diversity. Over 40-years, natural products played a powerful role as established cancer chemotherapeutic agents, either in their naturally occurring forms or their synthetically modified forms. ${ }^{5}$ For example, antitumor antibiotics from microbes include the anthracyclines (such as doxorubicin), bleomycin, dactinomycin (actinomycin), and mitomycin C. In turn, members of four classes of plant-derived compounds are used widely as antitumor agents, namely, the bisindole (vinca) alkaloids, the camptothecins, the epipodophyllotoxins, and the taxanes. ${ }^{6}$ In addition, there are several examples of promising natural product-derived antineoplastic agents currently in advanced clinical development or recently approved, not only from microbes (e.g., the epothilones and the enediynes) and plants (e.g., the combretastatin and homoharringtonine analogs), but also of marine origin (e.g., the bryostatins, ecteinascidin 743 , kahalalide F). ${ }^{5}$ Of a total of 155 anticancer agents approved for use in Western medicine and Japan since the 1940s, 47\% were classified as either natural products (14\%) semi-synthetic derivatives of natural products $(28 \%)$, or otherwise derived from natural products $(5 \%) .{ }^{5}$ Among the largest groups of taxonomically identified classes of organisms that may be studied as sources of new anticancer drugs are arthropods, higher plants, and marine 
invertebrates. ${ }^{7}$ In addition, natural product researchers have examined other taxonomic classes of organisms found all over the world, including algae, bacteria, fungi, and even terrestrial vertebrates. ${ }^{5}$ Natural product drug discovery for anticancer agents requires special procedures involved with sample collection, inclusive of the development of "benefit-sharing" agreements with source countries, whether the samples are of marine or terrestrial origin. $^{8}$

There is a tendency for natural product chemists to specialize on the types of organisms they work, such higher plants or marine fauna, due to the different methods of organism collection and work-up in the laboratory. ${ }^{5}$ However, there is increasing evidence that the same secondary metabolite of significance as a potential anticancer agent may be produced by more than one type of organism. ${ }^{9}$

\section{Plant Compounds with Anticancer Properties}

The plant based drug discovery give rise to the development of anticancer agents, including plants (paclitaxel, etoposide, campto- thecin, vinblastine, vincristine, topotecan, and irinotecan). Beside this there is various agents identified from fruits and vegetables can used in anticancer therapy (Table 1) include spices yielding biologically active components such as curcumin, lycopene, saponins, isoflavones, cucurbitacins, phytosterols, resveratrol, and others. ${ }^{10}$ There are compounds which have been identified and extracted from terrestrial plants for their anticancer properties include alvaradoin $\mathrm{E}$ (bioactivity-directed fractionation of an extract of the leaves of alvaradoa haitiensis Urb. (picramniaceae). ${ }^{11}$ Pancratistatin 3,4-O-cyclic phosphate sodium salt (pancratistatin, a phenanthridone alkaloid, from the bulbs of the plant Pancratium littorale Jacq. (Amaryllidaceae)). ${ }^{12}$ Polyphenolic compounds include (flavonoids which constitute a large family of plant secondary metabolites as anthocyanins, flavones, flavonols and chalcones ${ }^{13}$; tannins ${ }^{14}$; curcumin $^{15}$; Resveratrol which found in foods including peanuts and grapes and red wine ${ }^{16}$ and gallacatechins which present in green tea. ${ }^{17}$ Brassinosteroids are naturally occurring compounds found in plants which have role in hormone signalling to regulate growth and cell differentiation, stem and root cells elongation and other roles such as tolerance against disease and stress. ${ }^{17}$

\begin{tabular}{|c|c|c|c|}
\hline $\begin{array}{l}\text { S. } \\
\text { No. }\end{array}$ & Scientific Name & $\begin{array}{c}\text { Administration of Drug (Compound/Crude Extract) to } \\
\text { Experimental Model }\end{array}$ & Mechanism of Action \\
\hline \multirow[b]{2}{*}{1} & \multirow{2}{*}{ Acacia catechu (L.f.) Willd. } & $\begin{array}{l}100 \mu \mathrm{g} / \mathrm{ml} \text { of catechin rich extract (AQCE) was used against MCF-7 } \\
\text { (Human breast adenocarcinoma cellline) }\end{array}$ & $\begin{array}{l}\text { Down regulation of NF- } \mathrm{KB} \text { and } \mathrm{AP}-\mathrm{I} \text { expression (cell } \\
\text { differentiation and proliferation). Decreases c-jun expression }\end{array}$ \\
\hline & & $\begin{array}{l}10-100 \mu \mathrm{g} / \mathrm{mL} \text { of } 70 \% \text { methanolic extract (ACME) from heartwood acts } \\
\text { against } 7,12 \text {-di methyl benz[a] anthracene induced mammary carcinoma } \\
\text { in Balb/c mice. }\end{array}$ & $\begin{array}{l}\text { Induces cell cycle arrest at subGI phase by increasing Bax/Bcl2 } \\
\text { ratio and activating caspase cascade which leads to the cleavage of } \\
\text { poly adeno ribose polymerase (PARP)-intrinsic pathway }\end{array}$ \\
\hline 2 & Allamanda cathartica $L$. & $\begin{array}{l}\text { Allamandin, } \beta \text {-amyrin, plumericin, isoplumericin, } \beta \text { sitosterol and ursolic } \\
\text { acid from leaves through molecular docking }\end{array}$ & $\begin{array}{l}\text { Inhibit cyclin dependent kinases (CDKI) protein regulates cell } \\
\text { cycle }\end{array}$ \\
\hline 3 & Aloe barbadensis Miller. & $\begin{array}{l}200 \mu \mathrm{mol} / \mathrm{L} \text { of aloin from leaves was used against HUVECs (human } \\
\text { umbilical vein endothelial cells) and SW620 (human colorectal cancer } \\
\text { cells)with the dosage of } 20 \mu \mathrm{mol} / \mathrm{L}\end{array}$ & $\begin{array}{l}\text { Apotosis and anti-angiogenesis: Suppresses activation of VEGF } \\
\text { receptor (VEGFR) } 2 \text { mediated c-src and JAK2. Phosphorylation } \\
\text { of STAT3 in endothelial cells. Down-regulates activated STAT3 } \\
\text { protein, expression of STAT3-regulated antiapoptotic (Bcl-xL), } \\
\text { proliferative (c-Myc) proteins. }\end{array}$ \\
\hline \multirow{3}{*}{4} & \multirow{3}{*}{ Anisomeles indica $L$. } & $40 \mu \mathrm{M}$ of ovatodiolide against renal cell carcinoma & Inhibits $\beta$-catenin signaling \\
\hline & & $\begin{array}{l}500 \mu \mathrm{g} / \mathrm{mL} \text { of aqueous extract from whole plants and } 30 \mu \mathrm{M} \text { apigenin was } \\
\text { used against } 12 \text {-O-tetradecanoyl phorbol-13-acetate (TPA)-induced } \\
\text { MCF-7 cells (Human breast adenocarcinoma) }\end{array}$ & $\begin{array}{l}\text { Anti-metastasis, anti- migration and anti- invasion: Downregulates } \\
\text { matrix metalloproteinase (MMP)- } 9 \text { enzymatic activities, mRNA } \\
\text { expression, nuclear factor (NF)- } \mathrm{B} \text { B subunit } \mathrm{p} 65 \text { and activator } \\
\text { protein (AP)-I subunit c-Fos proteins expression in nucleus }\end{array}$ \\
\hline & & $\begin{array}{l}10,20 \text { and } 40 \mu \mathrm{M} \text { of ovatodiolide from whole plant were used against } \\
\text { MDA-MB-23I }\end{array}$ & $\begin{array}{l}\text { Cancer cell growth inhibition and proliferation: Prevents } \\
\text { phosphorylation of upstream signal IkB kinase. It also suppresses } \\
\text { activation of c-Jun } \mathrm{N} \text {-terminal kinase, p } 38 \text { mitogen-activated } \\
\text { protein kinase, phosphatidylinositol 3-kinase and Akt }\end{array}$ \\
\hline \multirow[t]{2}{*}{5} & \multirow[t]{2}{*}{ Bauhinia racemosa $L$. } & $\begin{array}{l}\text { Methanol extract from stem bark used against } \mathrm{N} \text {-nitrosodiethyl amine } \\
\text { (NDEA) induced hepato carcinogenesis in wister albino rats }\end{array}$ & $\begin{array}{l}\text { Chemoprevention: It suppresses nodule development or hepato } \\
\text { cellular lesion formation. It decreases lipid peroxidation and } \\
\text { enhances antioxidants levels by reducing the formation of free } \\
\text { radicals. }\end{array}$ \\
\hline & & $\begin{array}{l}50,100 \text { and } 200 \mathrm{mg} / \mathrm{kg} \text { of methanolic extract from stem bark against } \\
\text { ehrlich ascites carcinoma (EAC) in swiss albinomice }\end{array}$ & $\begin{array}{l}\text { Before treating drug: Increased level of serum enzymes, bilirubin } \\
\text { and decreased protein and uric acid level. Elevated amount of MDA } \\
\text { (malondialdehyde) decreased level of antioxidants. }\end{array}$ \\
\hline 6 & Bauhinia variegata $L$ & $\begin{array}{l}\text { Ethanol extract from bark and stem were used against HeLa, Dalton's } \\
\text { ascetic lymphoma, leukemia and ovariancancer }\end{array}$ & Arrest G0/GI phase \\
\hline 7 & Butea monosperma $L$. & $\begin{array}{l}100 \mathrm{mg} / \mathrm{kg} \text { and } 25 \mathrm{mg} / \mathrm{kg} \text { of aqueous extract from flower acts against } \\
\text { Huh7 } \mathrm{and} \text { HepG2 cells (hepatoma cells) }\end{array}$ & $\begin{array}{l}\text { Arrest in GI phase down-regulates MAP kinase and SAPK/JNK } \\
\text { signaling pathways }\end{array}$ \\
\hline \multirow[b]{2}{*}{8} & \multirow[b]{2}{*}{ Cajanus cajan $L$. } & 15 or $30 \mathrm{mg} / \mathrm{kg}$ of cajanin stilbene acid was used against MCF-7 & $\begin{array}{l}\text { Induce } \mathrm{G} 2 \mathrm{M} \text { arrest and apoptosis by activating the } \\
\text { mitochondrialpathway }\end{array}$ \\
\hline & & $\begin{array}{l}64 \mu \mathrm{M} \text { of cajanol (5-hydroxy-3-(4-hydroxy-2- methoxyphenyl)-7- } \\
\text { methoxychroman-4-one) from root }\end{array}$ & $\begin{array}{l}\text { ROS-mediated mitochondria-dependent pathway induces } \mathrm{G}_{2} / \mathrm{M} \\
\text { phase and apoptosis inhibits expression of } \mathrm{Bcl}-2 \text { and induction bax } \\
\text { expression leads to activation of caspase- } 9 \text { and caspase- } 3 \text { cascade, } \\
\text { which is involved in PARPcleavage }\end{array}$ \\
\hline
\end{tabular}




\begin{tabular}{|c|c|c|c|}
\hline 9 & Calotropis gigantea $L$. & $\begin{array}{l}\text { I, } 5 \text { and } 10 \mathrm{nM} \text { of cardenolides and calotropin from root bark used } \\
\text { against DLDI, HCTII } 6 \text { and SW480 } 99\end{array}$ & $\begin{array}{l}\text { Phosphorylation and degradation of } \beta \text {-catenin by casein kinase } I \alpha \\
\text { inhibits Wnt signaling. }\end{array}$ \\
\hline 10 & $\begin{array}{l}\text { Cardiospermum } \\
\text { halicacabum } L \text {. }\end{array}$ & $\begin{array}{l}<20 \mu \mathrm{g} / \mathrm{ml} \text { of } \mathrm{n} \text {-hexane extract from seeds was used against MCF-7 } \\
\text { (Breast cancer cell line) }\end{array}$ & Anti-proliferative activity \\
\hline II & $\begin{array}{l}\text { Cissus quadrangularis } \\
\text { Linn. }\end{array}$ & $\begin{array}{l}\text { Acetone extract from stem used against } \mathrm{A} 43 \mathrm{I} \text { (Human skin epidermoid } \\
\text { carcinoma) cellline }{ }^{21}\end{array}$ & $\begin{array}{l}\text { Bax-Bcl2 ratio, release of cytochrome c from mitochondria to } \\
\text { cytoplasm, cleavage of PARP }\end{array}$ \\
\hline \multirow[t]{2}{*}{12} & \multirow[t]{2}{*}{ Curcuma zedoaria $C$. } & $\begin{array}{l}500 \mathrm{mg} / \mathrm{kg} \text { of isocurcumenol was used for A549 (Lung carcinoma), } \\
\mathrm{KB} \text { (nasopharyngeal carcinoma), K562 (leukemic), daltons lymphoma } \\
\text { ascitescells }\end{array}$ & $\begin{array}{l}\text { Immuno modulation, immuno stimulation, effects on humoral } \\
\text { immune response, anti-angioneogenesis activity }\end{array}$ \\
\hline & & $\begin{array}{l}400 \mu M \text { of } \alpha \text {-curcumene from Rhizome acts against SiHa cells (Human } \\
\text { ovarian cancer) }\end{array}$ & $\begin{array}{l}\text { Mitochondrial cytochrome c complex with Apaf-I and pro-form of } \\
\text { caspase- } 9 \text { activates caspase- } 3 \text { and caspase- } 9 \text {. }\end{array}$ \\
\hline 13 & Dioscorea bulbifera $L$. & $\begin{array}{l}30 \mathrm{mg} / \mathrm{ml} \text { of ethyl acetate soluble fraction of } 75 \% \text { ethanol extract of the } \\
\text { rhizomes was acts against JB6 (Mouse epidermal) cell lines induced by } \\
\text { 12-O-tetra de canoylphorbol- } 13 \text {-acetate (TPA) }\end{array}$ & Onco-protein kinase activation and reactive oxygen burst \\
\hline \multirow[t]{2}{*}{14} & \multirow[t]{2}{*}{ Drosera indica $L$. } & $\begin{array}{l}250,500 \mathrm{mg} / \mathrm{kg} \text { of ethanol and } 500 \mathrm{mg} / \mathrm{kg} \text { of aqueous extract from whole } \\
\text { plant used against dalton lymphoma ascites (DLA) cells in male and } \\
\text { female adult swiss albino mice }\end{array}$ & $\begin{array}{l}\text { Increases caspase-3 activity and decreases DNA, RNA and protein } \\
\text { content. Cell growth inhibition through antioxidant property }\end{array}$ \\
\hline & & $\begin{array}{l}250 \mathrm{mcg} / \mathrm{ml} \text { ethanol and aqueous extract was used against ehrlich ascitic } \\
\text { carcinoma (EAC) cell line }\end{array}$ & $\begin{array}{l}\text { Anti tumour: Lactate dehydrogenase (LDH) leakage and increased } \\
\text { scavenging effect }\end{array}$ \\
\hline 15 & Elephantopus scaber $L$. & 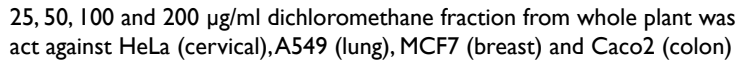 & $\begin{array}{l}\text { Apoptosis: Enhanced sub G0 content and micronuclei formation. } \\
\text { Genotoxicity. Inhibited MDR transporters (ABCBI and ABC G2) }\end{array}$ \\
\hline \multirow{2}{*}{16} & \multirow{2}{*}{ Embelia ribes Burm. } & $10-30 \mu \mathrm{M}$ of embelin from fruits used against MCF7 & $\begin{array}{l}\text { Reduction in TNF- } \alpha \text { and synthesized as pro-TNF- } \alpha \text { then released } \\
\text { to extra cellular space by TNF- } \alpha \text { converting enzyme. }\end{array}$ \\
\hline & & Embelin from fruits used for molecular docking (breast cancer cells) & $\begin{array}{l}\text { Inactivation of metastatic signaling: MMPs, VEGF and hnRNP-K } \\
\text { transcriptional attenuation of mortalin and activation of } p 53\end{array}$ \\
\hline 17 & Gymnema sylvestre $R \cdot B r$ & $\begin{array}{l}121 \mu g \text { and } 250 \mu g \text { of aqueous extract from leaves was used against Hep2 } \\
\text { (Liver cancer) cells }\end{array}$ & Anti-proliferation: Increases intracellular ROS levels \\
\hline 18 & Jatropha gossypifolia $L$. & $\begin{array}{l}10 \mu \mathrm{g} / \mathrm{ml} \text { of whole plant ethanolic extract acts against MCF-7 (Breast } \\
\text { cancer cells) }\end{array}$ & $\begin{array}{l}\text { Pro-apoptotic and anti-adhesive effects: Decreases } \beta \mid \text { - integrin } \\
\text { expression and phosphorylation of the focal adhesion kinase at } \\
\text { Tyr397 }\end{array}$ \\
\hline 19 & Kaempferia galanga $L$. & $\begin{array}{l}\text { Ethyl p methoxy cinnamate from Rhizome was used against HepG2 cells } \\
\text { (Human hepatocellular liver carcinoma) }\end{array}$ & $\begin{array}{l}\text { Apoptotic induction and inhibition of proliferation: Increase subG0 } \\
\text { cell population }\end{array}$ \\
\hline 20 & Kaempferia rotunda $L$. & $\begin{array}{l}500 \mathrm{mg} / \mathrm{Kg} \text { of chloroform extract and } 20 \mathrm{mg} / \mathrm{Kg} \text { of pinostrobin from } \\
\text { Rhizome acts against T47D (Human breast cancer cell lines) }\end{array}$ & Suppress c-Myc expression \\
\hline \multirow{3}{*}{21} & \multirow{3}{*}{ Lantana camara L. } & $\begin{array}{l}15 \mathrm{mM} \text { of pentacyclic triter penoids-reduced Lantadenes } \mathrm{A} \text { and } \mathrm{B} \text { used } \\
\text { against HL-60 cells. }\end{array}$ & $\begin{array}{l}\text { Induction of apoptosis: Suppresses the production of nitrite, TNF- } \alpha \\
\text { and iNOS gene expression }\end{array}$ \\
\hline & & $\begin{array}{l}20,40,80 \mathrm{mg} / \mathrm{kg} \text { of Ursolic acid stearoyl glucoside act against Induced } \\
\text { hepato cellular carcinoma in wistar rats by diethylnitrosamine (DENA). }\end{array}$ & $\begin{array}{l}\text { It suppresses free radical formation by scavenging the hydroxyl } \\
\text { radicals. Modulates the level of lipid peroxidation and increases the } \\
\text { endogenous antioxidant enzymes level }\end{array}$ \\
\hline & & $\begin{array}{l}30 \mu \mathrm{g} / \mathrm{mL} \text { of ethanolic extract from Leaves act against MCF-7 (Human } \\
\text { breast cancer cell line) }\end{array}$ & $\begin{array}{l}\text { Bid and bax was increased and Bcl- } 2 \text { was decreased after drug } \\
\text { treatment. It also modulates cleavage of caspase-8, caspase- } 9 \text { and } \\
\text { poly (ADP-ribose) polymerase(PARP) }\end{array}$ \\
\hline \multirow[b]{2}{*}{22} & \multirow{2}{*}{ Lawsonia inermis $L$. } & $\begin{array}{l}30 \mu g / m l-I \text { of leaves chloroform extract act against Hep2 cells and Caco2 } \\
\text { (colon) }\end{array}$ & Down regulation of c-myc expression \\
\hline & & $\begin{array}{l}180 \mathrm{mg} / \mathrm{kg} \text { of ethanolic crude extract from root was used against Dalton's } \\
\text { lymphoma ascites. }\end{array}$ & $\begin{array}{l}\text { Enhances the activities of catalase, glutathione peroxidase and } \\
\text { glutathione } \mathrm{S} \text { transferase and increases vitamin } \mathrm{C}, \mathrm{E} \text { and reduced } \\
\text { glutathione level. }\end{array}$ \\
\hline \multirow{4}{*}{23} & \multirow{4}{*}{ Leea indica Burm. } & $\begin{array}{l}40 \mathrm{mg} / \mathrm{kg} / \text { day of methanolic extract acts against ehrlich ascites carcinoma } \\
(\mathrm{EAC}) \text { cells in swiss albino mice }\end{array}$ & cytotoxicity \\
\hline & & $\begin{array}{l}60 \mu \mathrm{M} \text { of mollic acid arabinoside was used against Ca Ski cervical cancer } \\
\text { cells }\end{array}$ & Induce mitochondrial mediated apoptosis \\
\hline & & $\begin{array}{l}60 \mu \mathrm{M} \text { of mollic acid xyloside (MAX) from leaves against Ca Ski cervical } \\
\text { cancer cells }\end{array}$ & $\begin{array}{l}\text { Decreases the expression of proliferative cell nuclear antigen, } \\
\text { increases sub-GI cells and arrest cells in } S \text { and } G 2 / M \text { phases }\end{array}$ \\
\hline & & $\begin{array}{l}500 \text { and } 1000 \mu \mathrm{g} / \mathrm{mL} \text { of ethyl acetate fraction was used against Ca Ski } \\
\text { cellline }\end{array}$ & $\begin{array}{l}\text { Inducing apoptosis: Accumulation of sub-GI cells, depletion of } \\
\text { intracellular glutathione and activation of caspase-3. }\end{array}$ \\
\hline \multirow{2}{*}{24} & \multirow{2}{*}{$\begin{array}{l}\text { Moringa oleifera } L \text {. } \\
\text { Moringaceae }\end{array}$} & $\begin{array}{l}50 \mu \mathrm{g} / \mathrm{ml} \text { of ethanolic extract from leaves, bark and seed showed activity } \\
\text { against MDA-MB-23I and HCT-8 (colorectal) }\end{array}$ & Anti-malignant properties:Arrest cell \\
\hline & & $\begin{array}{l}50-400 \mu \mathrm{g} / \mathrm{ml} \text { of leaf extract against HepG2 (Hepato cellular carcinoma } \\
\text { cells) and A549 non-small cell lung cancer }\end{array}$ & Anti-proliferation and apoptosis \\
\hline 25 & Oroxylum Indicum $L$. & $20 \mu \mathrm{M}$ of baicalein from stem bark against CT-26 (colon carcinoma) & Inhibit activation of pro-PDGF-A, B and pro-VEGF C \\
\hline 26 & Oxalis corniculata Linn. & $\begin{array}{l}100 \text { and } 400 \mathrm{mg} / \mathrm{kg} \text { of Ethanolic extract from Whole plant for Ehrlich } \\
\text { ascites carcinoma (EAC)-induced in swiss albino mice }\end{array}$ & $\begin{array}{l}\text { Antitumor and antioxidant activity: Increase intotalprotein, } \\
\text { albumincontent,catalaseand reduced glutathione levels. Decrease in } \\
\text { AST,ALT and ALP contents, liver MDA level }\end{array}$ \\
\hline
\end{tabular}




\begin{tabular}{|c|c|c|c|}
\hline \multirow{3}{*}{27} & \multirow{3}{*}{ Physalis minima $L$. } & $\begin{array}{l}25-100 \mathrm{~g} / \mathrm{ml} \text { of chloroform extract from whole plant was used against } \\
\mathrm{NCl}-\mathrm{H} 23 \text { (Human lung adenocarcinoma) }\end{array}$ & $\begin{array}{l}\text { Inhibit cell proliferation and induce apoptosis:Activation of c-myc, } \\
\text { caspase- } 3 \text { and p } 53 \text { gene expression }\end{array}$ \\
\hline & & $\begin{array}{l}6.25 \mu \mathrm{g} / \mathrm{mL} \text { of Physalin F used against T-47D cells (Human breast } \\
\text { carcinoma) }\end{array}$ & $\begin{array}{l}\text { Chemoprevention / apoptosis:Activation of caspase- } 3 \text { and c-myc } \\
\text { pathways due to the presence of cyclo hexanone and epoxy } \\
\text { moieties. }\end{array}$ \\
\hline & & $\begin{array}{l}25-100 \mathrm{~g} / \mathrm{ml} \text { of chloroform extract from whole plant act against Caov-3 } \\
\text { (Human ovarian carcinoma) }\end{array}$ & Apoptosis and autophagy \\
\hline 28 & Polyalthia longifolia Sonn. & $50 \mu \mathrm{g} / \mathrm{ml}$ of was chloroform extract from Leaves against HL-60 & Induce intrinsic or mitochondrial-dependent apoptotic pathway \\
\hline 29 & Tecomella undulate $D$. & $\begin{array}{l}30 \mu \mathrm{g} / \mathrm{ml} \text { of undulatoside- } \mathrm{A} \text {, undulatoside- } \mathrm{B} \text { and tecomin from bark acts } \\
\text { against } \mathrm{K} 562 \text { (chronic myeloid leukemia cells) }\end{array}$ & $\begin{array}{l}\text { Cell cycle arrest at } S \text { phase, increase in Annexin } V \text { positive cells. } \\
\text { Increase in FAS, FADD levels and activation of caspase } 8 \text { and } 3 / 7\end{array}$ \\
\hline 30 & Terminalia chebula $R$. & $\begin{array}{l}\text { I00 } \mu \mathrm{l} \text { of chebulagic acid from fruits showed apoptosis in COLO-205 } \\
\text { cells }\end{array}$ & Inhibition activity of COX and 5-LOX \\
\hline \multirow[b]{2}{*}{31} & \multirow[b]{2}{*}{ Tinospora cordifolia T. } & $\begin{array}{l}100 \text { and } 200 \mathrm{mg} / \mathrm{kg} \text { of palmatine (alkaloid) from stem against } \\
7,12 \text {-dimethylbenz(a) anthracene (DMBA) induced skin carcino genesis in } \\
\text { swiss albino mice. }\end{array}$ & Antioxidant and chemo-preventive activity \\
\hline & & $100 \mu \mathrm{l}$ of Hexane fraction act against EAT (Ehrlich ascites tumor). & $\begin{array}{l}\text { Apoptosis signals activates caspase- } 8 \text {, its substrate BID protein } \\
\text { releases cytochrome } C \text { to bind Apaf-I which induces auto- } \\
\text { activation of caspase- } 9 \text {, which in turn activates caspase- } 3 \text {. It cleaves } \\
\text { poly-ADP-ribose polymerase, lamins and inhibitor of caspase } \\
\text { activated DNase (ICAD). }\end{array}$ \\
\hline 32 & $\begin{array}{l}\text { Triumfetta rhomboidea } \\
\text { Jacq. (Tiliaceae) }\end{array}$ & $\begin{array}{l}100 \text { and } 200 \mathrm{mg} / \mathrm{kg} \text { of leaves methanolic extract used against ehrlich } \\
\text { ascites carcinoma (EAC) DLA bearing male swiss albino mice. }\end{array}$ & $\begin{array}{l}\text { Antitumor and antioxidant activity: Decreases the level of lipid } \\
\text { peroxidation and increases glutathione (GSH), superoxide } \\
\text { dismutase (SOD) and catalase level }\end{array}$ \\
\hline 33 & Urginea indica Roxb. & $\begin{array}{l}75 \mu \mathrm{gml}-\mathrm{I} \text { of Glycoprotein from bulbs act against HUVECs and EAT cells } \\
\text { in swiss albino mice }\end{array}$ & $\begin{array}{l}\text { Antiangiogenic and proapoptotic activity: Inhibition of } \\
\text { translocation of nuclear factor kappa B to the nucleus thus } \\
\text { decreases the expression of vascular endothelial growth factor } \\
\text { gene }\end{array}$ \\
\hline \multirow[t]{2}{*}{34} & \multirow{2}{*}{$\begin{array}{l}\text { Vitex negundo } L . \\
\text { (Verbenaceae) }\end{array}$} & $\begin{array}{l}\text { I0 } \mu \mathrm{g} / \mathrm{mL} \text { of chrysoplenetin and chrysosplenol D used against PANC-I } \\
\text { (Human pancreatic cancer) cells, NCI-H522 (lung), OVCAR-3 } \\
\text { (ovarian) and PC-3 (prostate) cells. }\end{array}$ & $\begin{array}{l}\text { Cytotoxicity and apoptotic morphological changes (DNA } \\
\text { fragmentation, nuclear condensation and membrane blebbing) }\end{array}$ \\
\hline & & $\begin{array}{l}4 \text { to } 6 \mu \mathrm{g} / \mathrm{mL} \text { of vitexin from i) Fruit iii) Seeds used against } \mathrm{COCl} \\
\text { (ovarian cancer cells) and MDA-MB-23II54 }\end{array}$ & $\begin{array}{l}\text { Apoptosis by caspase activates poly (ADP ribose) polymerase } \\
\text { (PARP) and cleaved into a COOH-terminal fragment }\end{array}$ \\
\hline
\end{tabular}

\begin{tabular}{|c|c|c|c|c|}
\hline No & Name of the Compound & Source of Organisms & Chemical Class & Cancer Target \\
\hline 1 & Arenamides A-C & $\begin{array}{l}\text { Actinomycete } \\
\text { (Salinispora arenicola) }\end{array}$ & Cyclohexa-depsipeptides & $\begin{array}{l}\text { Human colon carcinoma cell line } \\
\text { (HCT-II6) }\end{array}$ \\
\hline 2 & Heteronemin & Sponge (Hyrtios sp.) & Sesterterpene & Leukemia (K562 cells) \\
\hline 3 & 6-bromoisatin & Whelk (Dicathais orbita) & Indole derivative & $\begin{array}{l}\text { Ovary, granulosa, Choriocarcinoma } \\
\text { (OVCAR-3, KGN, Jar) }\end{array}$ \\
\hline 4 & Tyrindoleninone & Whelk (Dicathais orbita) & Indole derivative & $\begin{array}{l}\text { Ovary, granulosa, Choriocarcinoma } \\
\text { (OVCAR-3, KGN, Jar) }\end{array}$ \\
\hline 5 & Cryptosphaerolide & $\begin{array}{l}\text { Ascomycete fungal strain } \\
\text { CNL-523 (Cryptosphaeria sp.) }\end{array}$ & Sesquiterpenoid & $\begin{array}{l}\text { Human colon carcinoma cell line } \\
\text { (HCT-II6) }\end{array}$ \\
\hline 6 & Makaluvamine A & sponge (Zyzzya fuliginosa) & Pyrroloquinoline & Colon cancer (HCT-I I6 cells) \\
\hline 7 & Ascididemin & $\begin{array}{l}\text { Actinomycete } \\
\text { (Salinispora arenicola) }\end{array}$ & Cyclohexa-depsipeptides & $\begin{array}{l}\text { Human colon carcinoma cell line } \\
\text { (HCT-II6) }\end{array}$ \\
\hline 8 & Lamellarin D & $\begin{array}{l}\text { Prosobranch mollusc of the genus } \\
\text { (Lamellaria) }\end{array}$ & Alkaloid & Leukemia \\
\hline 9 & Spongistatin I & $\begin{array}{l}\text { Sponges (Spirastrella } \\
\text { spinispirulifera and Hyrtios erecta) }\end{array}$ & Macrocyclic lactone & Leukemia (Jurkat cells) \\
\hline 10 & Streptochlorin & Streptomyces sp. & Methyl pyridine & Leukemia (U937 cells) \\
\hline
\end{tabular}

\section{Anticancer Compound from Marine Flora}

Marine floras include microflora (bacteria, actinobacteria, cyanobacteria and fungi, microalgae, macroalgae, and flowering plants (mangroves and other halophytes) contain a massive number of natural products and novel chemical structures with unique activities that may be useful in finding the potential drugs with major efficacy and specificity forhuman treatment ${ }^{19}$ (Table 2). The marine organisms produce novel chemicals to withstand extreme variations in their environment, and the chemicals produced are unique in diversity, structural, and functional features. ${ }^{20}$ Mostly invertebrates that include sponges, soft corals, sea fans, sea hares, nudibranchs, bryozoans, and tunicates are proven to be the potent sources of drugs. ${ }^{21}$ It is now believed that microbial flora present in the invertebrates are responsible for the production of medicinal compounds. Marine floras are rich in biologically active and medicinally potent chemicals as polyphenols, polysaccharides and alkaloids are the most predominant group of compounds which are applicable for antioxidant and anticancer activities. ${ }^{19}$ 


\begin{tabular}{|c|c|c|c|c|}
\hline Bacteria & $\begin{array}{l}\text { Gram } \\
(+ \text { or }-)\end{array}$ & Activity & Target organism & Disease \\
\hline $\begin{array}{l}\text { Pseudomonas } \\
\text { bromoutilis }\end{array}$ & - & Anticancer & $\begin{array}{l}\text { Staphylococcus aureus, Streptococcus } \\
\text { pneumoniae, Streptococcus pyogenes }\end{array}$ & $\begin{array}{l}\text { Pneumonia, osteitis, arthritis, endocarditis, } \\
\text { localized abscesses }\end{array}$ \\
\hline $\begin{array}{l}\text { Chromobacteria } \\
\text { marinum }\end{array}$ & - & Antibacterial & $\begin{array}{l}\text { Escherichia coli, Pseudomona aureginosa, } \\
\text { Staphylococcus aureus }\end{array}$ & $\begin{array}{l}\text { Pneumonia, osteitis, arthritis, endocarditis, } \\
\text { localized abscesses }\end{array}$ \\
\hline $\begin{array}{l}\text { Flavobacteria } \\
\text { uliginosum }\end{array}$ & - & Anticancer & Sarcoma-I 80 cells & Viral tumor \\
\hline Bacillus sp. & + & Anticancer & HCT-I I6 cells & Colorectal Cancer \\
\hline Lactococcus lactis & + & Anticancer & $\begin{array}{l}\text { Human } \\
\text { papilloma virus type } 16(\mathrm{HPV}-16)\end{array}$ & Colorectal Cancer \\
\hline $\begin{array}{l}\text { Staphylococcus } \\
\text { aureoverticillatus }\end{array}$ & + & Anticancer & Tumor cells & Tumors \\
\hline $\begin{array}{c}\text { Marinobacter } \\
\text { drocarbonoclasticus }\end{array}$ & - & $\begin{array}{l}\text { Antibacterial } \\
\text { (siderofore) }\end{array}$ & $\begin{array}{l}\text { Mycobacteria tuberculosis, Bacillus } \\
\text { anthracis }\end{array}$ & Tuberculosis, carbuncle (anthraxlike) \\
\hline
\end{tabular}

Marine bacteria: Produce secondary metabolites which have anticancer agents (e.g., eleutherobin, discodermolide, bryostatins, and sarcodictyin $)^{23}$ as in Table 3. Most of marine bacteria produces toxins which are useful in neurophysiological and neuropharmacological studies. ${ }^{24}$ Only a few marine bacteria can be isolated under laboratory conditions and there is an urgent need to isolate the bacteria that produce unique and novel natural products. ${ }^{25}$

Marine actinomycetes: Received very recent attention. Gutingimycin is a highly polar trioxacarcin derivative from streptomyces species, isolated from sediment of the Laguna de Terminos, Gulf of Mexico. ${ }^{19}$ The same Streptomyces species also yields trioxacarcins D-F, in addition to the known trioxacarcins A-C. Among the antibiotic-producing microbes, marine actinomycetes within the family micromonosporaceae are very promising. ${ }^{27}$ These microbes revealed to be a promising sources of anticanceragents that target proteasome function.

Thiocoraline is a novel bioactive depsipeptide isolated from Micromonospora marine, a microorganism located in the mozambique strait that inhibits ribonucleic acid (RNA) synthesis. ${ }^{28}$

Marine fungi: Marine fungi are least studied than terrestrial fungi. Obligate marine fungi are still an unexplored resource, although, marine facultative fungi, have been studied due to their production of new metabolites which are not found in terrestrial fungi. ${ }^{29}$ Recently more interest has been generated on studying biologically active metabolites from higher fungi (basidiomycetes), endophytic fungi and filamentous fungi from marine habitats, the symbiotic lichens on its anticancer activity. ${ }^{30}$

Marinemacro algae (Cyanobacteria): Marinemicro algae is one of the potential organisms which can be the richest sources of potent bioactive compounds including toxins with potential for pharmaceutical applications. ${ }^{31}$ More than $50 \%$ of the marine cyanobacteria are potentially exploitable for extracting bioactive substances which are effective in killing the cancer cells. ${ }^{19}$ Scytonemin is a protein serine/threonine kinase inhibitor isolated from the cyanobacterium Stigonema sp. and this compound is a yellowgreen ultraviolet sunscreen pigment, known to be present in the extracellular sheaths of different genera of aquatic and terrestrial blue-green algae. ${ }^{23}$ Largazole derived from Symploca sp. is a novel chemical scaffold with fabulous antiproliferative activity. ${ }^{19}$ Other compounds, apratoxin A, isolated from a strain of Lyngbya boulloni, ${ }^{32}$ coibamide A derived from a strain of Leptolyngbya, ${ }^{33} \mathrm{cu}-$ racin-A, isolated from the organic extracts of curacao collections of Lyngbya majuscule. ${ }^{34}$

Marine macro algae (Seaweed): Marinemacro algae many researchers have worked on the antioxidant, antitumor, and immunomodulating activities of seaweeds as edible seaweed like Palmaria palmate, ${ }^{35}$ the alcoholic extract of the red alga Acanthophora spicifera, ${ }^{36}$ the seaweeds Acanthaphora spicifera, ${ }^{37}$ Ulva reticulate, ${ }^{38}$ Gracilaria foliifera, ${ }^{39}$ the brown seaweed Sargassum thunbergii, ${ }^{40} \mathrm{fu}-$ coidan from Ascophyllum nodosum, ${ }^{41}$ stylopoldione from Stypodium $s p .,{ }^{19}$ condriamide-A from Chondria sp., ${ }^{42}$ caulerpenyne from caulerpa sp., ${ }^{43}$ two compounds meroterpenes and usneoidone isolated from Cystophora sp., ${ }^{44}$ phloroglucinol and its polymers namely eckol (a trimer), ${ }^{45}$ phlorofucofuroeckol A (a pentamer), ${ }^{45}$ dieckol and 8,8 '-bieckol (hexamers) isolated from the brown alga eisenia bicyclis and padina ${ }^{45}$ owing to their biological properties.

Mangroves and other higher marine plants: Mangroves have long been used in fisher-folk medicine to treat diseases. Based on traditional knowledge and preliminary scientific work, sixteen higher marine plants considered asa source of anticancer drugs ${ }^{19}$ (Table 4). A sulphur containing alkaloid, 1,2-dithiolane (brugine) isolated form Bruguiera sexangula, ribose derivative of 2-Benzoxazoline isolated from Acanthus ilicifolius and tea from the mangrove plant Ceriops decandra has shown anticancer activity. ${ }^{46}$

\section{Microorganisms with Anticancer Properties}

Small organic molecules derived naturally from microorganisms have provided a number of beneficial cancer chemotherapeutic drugs. ${ }^{5}$ Introduce microorganisms into the body leads to the activation of various immune mechanisms, which manifests itself in increasing the number and recruitment of congenital immune cells, activation of acquired immunity cells, and production of proinflammatory cytokine. ${ }^{48}$ It is assumed that the rallied immune system, by intentionally introducing microorganisms into the oncological patient, is able to at least limit the development 


\begin{tabular}{|c|c|c|c|c|c|}
\hline No & Host Plant & Fungal Endophyte & $\begin{array}{l}\text { Isolated Cytotoxic } \\
\text { Compound/s }\end{array}$ & $\begin{array}{l}\text { Tested Cell } \\
\text { Line/s }\end{array}$ & Cytotoxicity \\
\hline \multirow{2}{*}{1} & \multirow{2}{*}{ Excoecaria agallocha } & Phomopsis sp. & \multirow{2}{*}{$\begin{array}{l}\text { 2-(7'-hydroxyoxooctyl)- } \\
\text { 3-hydroxy-5-methoxyben- } \\
\text { zeneacetic acid ethyl ester }\end{array}$} & HEp2 & 25 \\
\hline & & ZSU-H76 & & HepG2 & 30 \\
\hline \multirow{3}{*}{2} & \multirow{3}{*}{ Rhizophora mucronata } & \multirow{3}{*}{ Pestalotiopsis sp. } & Cytosporones J-N & L5I78Y & \multirow{3}{*}{$\begin{array}{l}\text { Not Active up to } \\
10 \mu \mathrm{g} / \mathrm{mL}\end{array}$} \\
\hline & & & Pestalasins A-E & HeLa & \\
\hline & & & Pestalotiopsoid A & $\mathrm{PCl} 2$ & \\
\hline \multirow{6}{*}{3} & \multirow{6}{*}{ Rhizophora mucronata } & \multirow{6}{*}{ Pestalotiopsis sp. } & Pestalotiopsone A & \multirow{6}{*}{ L5178Y } & NA \\
\hline & & & Pestalotiopsone B & & NA \\
\hline & & & Pestalotiopsone $\mathrm{C}$ & & NA \\
\hline & & & Pestalotiopsone D & & NA \\
\hline & & & Pestalotiopsone E & & NA \\
\hline & & & Pestalotiopsone $\mathrm{F}$ & & 26.89 \\
\hline \multirow{2}{*}{4} & \multirow{2}{*}{ Not mentioned } & \multirow{2}{*}{$\begin{array}{l}\text { Mangrove endophytic } \\
\text { fungus No. ZSU } 44\end{array}$} & \multirow{2}{*}{ Secalonic acid D } & HL60 & 0.38 \\
\hline & & & & K562 & 0.43 \\
\hline \multirow{3}{*}{5} & \multirow{3}{*}{ Excoecaria agallocha } & \multirow{3}{*}{ Pestalotiopsis sp. } & Phomopsis-H76 A & KB & Allthecompoundsare \\
\hline & & & Phomopsis-H76 B & KBv200 & Inactiveagainstallthe \\
\hline & & & Phomopsis-H76 C & MCF7 & Tested cell lines \\
\hline \multirow{2}{*}{6} & \multirow{2}{*}{ Kandelia woody tissue } & Halorosellinia sp. & I-hydroxy-3-methyl & KB & 3.17 \\
\hline & & Guignardia sp. & anthracene-9, 10-dione & KBv200 & 3.21 \\
\hline \multirow{2}{*}{7} & \multirow{2}{*}{ Sonneratia apetala } & \multirow{2}{*}{ Zh6-BI (unidentified) } & 3R,5R-Sonnerlactone & KYMDP & 42.4 \\
\hline & & & 3R,5S-Sonnerlactone & 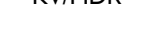 & 41.6 \\
\hline & & & & BT474 & 4.98 \\
\hline & & & Teruma & SW620 & 4.84 \\
\hline 8 & Xylocarbus aranotum & ycon didntifol & Moulin D & BT474 & $>10$ \\
\hline 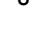 & Aytocerpas grarcicum & A & 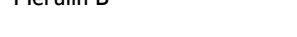 & SW620 & $>10$ \\
\hline & & & & BT474 & 1.57 \\
\hline & & & 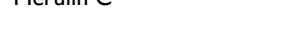 & SW620 & 4.11 \\
\hline & & & & 95-D & 0.57 \\
\hline & & & & HepG2 & 6.5 \\
\hline 0 & 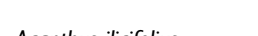 & Rotring & Dariring & HeLa & $>100$ \\
\hline 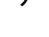 & Acaminus miliforias & restarviopsis sp. & rencinomine & KB & $>100$ \\
\hline & & & & KBv200 & $>100$ \\
\hline & & & & HEp2 & $>100$ \\
\hline 10 & Unidentified mangrove & Pestolationcic ch & Paeciloxocins A & Hon & 1 \\
\hline 10 & (Taiwan Strait) & restarotiopsis sp. & Paeciloxocins B & Перजц & 65 \\
\hline & & & 5 & A549 & NR \\
\hline 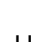 & 5 & D & Expansois A & HL-60 & 15.7 \\
\hline & Lxcoecuría aguiverita & 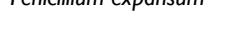 & & A549 & 1.9 \\
\hline & & & Lxpansots D & $\mathrm{HL}-60$ & 5.4 \\
\hline & & & 5-O-methyl-2'-methoxy-3'- & HEp2 & 4 \\
\hline & & & methylalpinumisoflavone & HepG2 & 11 \\
\hline & & & Alterporriol K & MDA-MB-435 & 26.97 \\
\hline & & & Alterporriol L & MDA-MB-435 & 13.11 \\
\hline 14 & Rhizophora mucronata & Irpex hynoides & Ethyl acetate extract & HEp2 & 125 \\
\hline 15 & Rhizophora annamalayan & Fusarium oxysporum & Taxol & NT & NT \\
\hline 16 & Bruguiera gymnorrhiza & Rhytidhysteron rufulum & Rhytidchromones A & MCF7 & 19.3 \\
\hline Com & ounds are included in the co & $m n$ "isolatedcompound/s". & NA-Not Active; NR-Not Reporte & NT-Nottested & \\
\hline
\end{tabular}


binding glycoprotein that belongs to the transferrin family. ${ }^{65}$

of cancer. ${ }^{49}$ This is a method in which microbes indirectly lead to cancer regression especially in those in whom other commonly used treatments have failed.

Bacteria: Bacteria can be applied in various forms for therapeutic purposes. Apart from the whole, living attenuated cells, we can use genetically engineered bacteria expressing particularly desirable factors. ${ }^{50}$ Microorganisms are also applied as vectors, which are carriers of specific chemotherapeutics agents or enzymes useful in thedestruction of cancer cell. This method allows a significant reduction of the side effects of treatment that usually accompany traditional chemotherapy. ${ }^{51}$ Moreover, there is a therapeutic potential to use bacterial secretion, for example, toxins. ${ }^{52}$ Their presence in the tumor environment could have destruct the cancer cells. The use of sporangial bacteria, which can survive under unfavorable environmental conditions, represents another approach, which has been applied in the experiments with Clostridium novyi. This microorganism prefers anaerobic conditions, which are found in the tumor. ${ }^{53}$ Instead of spreading over the entire organism, the bacteria are directed to the tumor site only, where they have the optimal conditions for growth. ${ }^{54}$ This bacterial property allows the patient to be protected against the development of serious infections. From the bacteria that used in cancer therapy (Mycobacterium bovis BCG is a strain of mycobacterium bovis developed by Albert Calmett and Camille Guérin as a tuberculosis vaccine ${ }^{55}$; Streptococcus pyogenes OK-43256; Clostridium novy ${ }^{57}$; Salmonella enterica ${ }^{50}$; serovar typhimurium which is obligate anaerobes and facultative anaerobes ${ }^{58}$; Clostridium histolyticum ${ }^{59}$; Magnetococcus marinus MC1 is a gram-negative cocci found in the Atlantic Ocean near Rhode Island, USA. ${ }^{60}$

Toxoplasma gondii: Toxoplasma gondii is an obligatory intracellularparasite. ${ }^{61}$ It is life-threatening to people with impaired immunity or pregnant women, who can suffer abortion or birth malformation. It turns out that the protozoan and its lysate, toxoplasma lysate antigen, can be used to treat cancer. ${ }^{60}$

Plasmodium falciparum: Plasmodium falciparum (Malaria) caused by Plasmodium sp., is one of the most common parasitic diseases in the world. ${ }^{62}$ Plasmodium falciparum is considered to be the most malignant causative agent of malaria because it aggregates erythrocytes and thrombocytes that adhere to the vascular endothelium, which can lead to the closure of vascular light and thus damage to vascular walls and even necrosis. However, despite all the negative features of the parasite, it can be used to treat cancer. ${ }^{63}$

\section{Natural Product with Anticancer Activity from Terrestrial Verte- brate and Invertebrate}

Mammals and milk: Natural product isolated from mammal source is poorly studied, throughout screening for the review little data were available. Ryan et al ${ }^{64}$ described four bovine meat-derived peptides that inhibit angiotensin-converting enzyme (ACE) and also exhibit anti-proliferative activity. A number of studies have reported the anticancer effects of milk protein-derived peptides on various cancer cells as the casein fraction-derived caseinophosphopeptides (CPPs) and lactoferrin is an $80-\mathrm{kDa}$ iron-
Amphibians: Amphibians skin secretions contain a wide range of biologically active compounds and have garnered attention due to their potential for drug development. ${ }^{66}$ Moreover, the Chinese traditionally administered secretions from frog skin and toad parotid glands for medicinal purposes since ancient times. Hundreds of those peptides have been identified since the discovery of the first antimicrobial peptide from amphibian skin. Some of the naturally occurring amphibian skin peptides and their analogs proven to be cytotoxic to tumor cells only and are promising anticancer agents for example, Alyteserin-2a, isolated from the midwife toad (Alytes obstetricans) ${ }^{67}$; ascaphin- 8 and XT-7 peptides obtained from the skin secretions of Ascaphus truei and Silurana tropicali $^{68}$; aurein peptides from the green and golden bell frog (Litoria aureus) and the southern bell frog (Litoria raniformis) ${ }^{69}$; dermaseptin B2 and B3, of the dermaseptin family, isolated from the South American tree frog (Phyllomedusa bicolor) ${ }^{70}$; dermaseptin L1 and phylloseptin L1, isolated from the lemur leaf frog (Agalychnis lemur). ${ }^{71}$

Reptilian: Reptilian peptides derived from crocodiles as the cationic antimicrobial peptides KT2, RT2 and RP9 from Crocodylus siamensis leukocyte extract proven to have a great anticancer activity. ${ }^{72} \mathrm{He}$ et $\mathrm{al}^{73}$ has reported antitumor peptides T1 and T2 derived from the enzymatic hydrolysates of the Chinese three-striped box turtle (Cuora trifasciata).

Animal venoms: Animal venoms and toxins consist of a complex mixture of proteins and peptides and are rich with biologically active peptides with potent anticancer activity. ${ }^{74}$ Among venomous animals, scorpions, is a source of peptidyl neurotoxins, which are used as tools to study different ion channels, such as the $\mathrm{Na}+$, $\mathrm{K}^{+}, \mathrm{Ca}^{+}$, and $\mathrm{Cl}^{-}$ion channels ${ }^{75}$ (Table 5). Chlorotoxin (CTX) is a small neurotoxin of 36 amino acids that was isolated from the venom Leiurus quinquestriatus scorpion. Initially, CTX was used as a pharmacological tool to characterize chloride channels. CTX can target glioma, small cell lung carcinoma, melanoma, neuroblastoma and medulloblastoma cells. ${ }^{76}$

Spider venom contain proteins and peptides including enzymes (such as proteases, phospholipases, andhyaluronidases), neurotoxins, and cytolytic peptides. ${ }^{77} \mathrm{~A}$ short cationic peptide latarcin $2 \mathrm{a}$ (Ltc2a) isolated from Lachesana tarabaevivenom ${ }^{78}$ have anticancer activity.

Venom from bees and wasps is now being studied to design and develop new therapeutic drugs from their venom. ${ }^{79}$ Melittin peptide (26 amino acid) isolated from the honey bee Apis mellifera, is the most studied and famous bee venom-derived peptide. It inhibits different cancer cells in vitro, including leukemic, lung tumor, astrocytoma, glioma, squamous carcinoma,ovarian carcinoma, hepatocellular carcinoma, renal cancer cells, prostate cancer and osteosarcoma. ${ }^{80}$ Unfortunately this peptide is toxic to both normal and cancer cells. mastoparan is 14 -amino acid cationic peptide isolated from Vespula lewisii venom that has shown in vitro anticancer activity. ${ }^{81}$ 
-

\begin{tabular}{|c|c|c|c|c|c|c|}
\hline Target & $\begin{array}{l}\text { The Major Mechanisms } \\
\text { of Action }\end{array}$ & Molecular Target & Drug & Drug Class & Indications & Clinical Phase \\
\hline \multirow{5}{*}{ Ion Channels } & \multirow{5}{*}{$\begin{array}{l}\text { The proliferationand } \\
\text { invasion of cancer cells }\end{array}$} & \multirow{2}{*}{$\begin{array}{l}\text { Chloride }\left(\mathrm{Cl}^{-}\right) \text {channels: } \\
\text { CLC3 }\end{array}$} & $\begin{array}{l}\text { I } 31|-T M 60| \\
(13 \mid I-C T X)\end{array}$ & Peptide (36aa) & Gliomas & Phase III \\
\hline & & & $\begin{array}{l}\text { BLZ-100 } \\
(\text { ICG-CTX) }\end{array}$ & Peptide (36aa) & Gliomas tumor marker forsurgery & Phase I \\
\hline & & Sodium $\left(\mathrm{Na}^{+}\right)$channels & AGAP & Peptide (66aa) & $\begin{array}{l}\text { Colon cancer cells, Malignant glioma } \\
\text { cells }\end{array}$ & Preclinical studies \\
\hline & & $\begin{array}{l}\text { Potassium }(\mathrm{K}+) \text { channels: } \\
\text { KVII.I (hERG) }\end{array}$ & Ergtoxin & $\begin{array}{l}\text { peptide } \\
(42-62 \mathrm{aa})\end{array}$ & Ovarian cancer cells & Preclinical studies \\
\hline & & $\begin{array}{l}\text { Transient receptor } \\
\text { potential(TRP) channels: } \\
\text { TRPV6 }\end{array}$ & SOR-CI3 & peptide( (3aa) & $\begin{array}{l}\text { Solid tumors with } \\
\text { overexpressing the TRPV6 ion channel }\end{array}$ & Phase I \\
\hline \multirow{6}{*}{ Integrins } & \multirow{6}{*}{$\begin{array}{l}\text { The invasion, migration, } \\
\text { angiogenesis, and } \\
\text { metastasis of cancer cells }\end{array}$} & \multirow{3}{*}{$\alpha_{v} \beta_{3}, \alpha_{v} \beta_{5}$} & \multirow{3}{*}{ Cilengitide } & \multirow{3}{*}{$\begin{array}{l}\text { Peptidomimetic } \\
\text { (5aa) }\end{array}$} & $\begin{array}{l}\text { I Glioblastoma with methylated } \\
\text { MGMT promoter }\end{array}$ & I Phaselll \\
\hline & & & & & $\begin{array}{l}2 \text { Glioblastoma with } \\
\text { unmethylated MGMTpromoter }\end{array}$ & 2 Phasell \\
\hline & & & & & 3 NSCLC & 3 Phasell \\
\hline & & $\alpha_{5} \beta_{1}$ & ATN-161 & Peptidomimetic & Malignant Glioma & Phase II \\
\hline & & $\begin{array}{l}\text { Five integrin receptors } \\
\left(\alpha_{v} \beta_{1}, \alpha_{v} \beta_{3}, \alpha_{v} \beta_{5},{ }_{v} \beta_{6}, \alpha_{5} \beta_{1}\right)\end{array}$ & GLPG0187 & Peptidomimetic & $\begin{array}{l}\text { Bone metastasis in metastatic breast } \\
\text { cancer }\end{array}$ & Phase I \\
\hline & & $\alpha_{v} \beta_{3}, \alpha_{v} \beta_{5}, \alpha_{5} \beta_{1}$ & Vicrostatin & Peptide(69aa) & Ovarian cancer, Gliomas & Preclinical studies \\
\hline $\begin{array}{l}\text { G protein-coupled } \\
\text { receptor }\end{array}$ & $\begin{array}{l}\text { The metastasis of cancer } \\
\text { cells }\end{array}$ & $\begin{array}{l}\text { Gastrin-releasing peptide } \\
\text { receptor }\end{array}$ & BAY86-7548 & Peptide (14aa) & Prostate cancer imaging & Phase II/III \\
\hline \multirow{4}{*}{$\begin{array}{l}\text { Membrane mol- } \\
\text { ecules }\end{array}$} & \multirow{4}{*}{$\begin{array}{l}\text { The disruption of cancer } \\
\text { cell membrane }\end{array}$} & \multirow{3}{*}{$\begin{array}{l}\text { Sialic acid-rich } \\
\text { glycoproteins, PS and PC, } \\
\text { heparansulfate }\end{array}$} & I MPI & I Peptide (14aa) & I Human leukemic Jurkatcells & \multirow{3}{*}{ Preclinical studies } \\
\hline & & & 2 Melittin & 2 Peptide (26aa) & $\begin{array}{l}2 \text { Human renal cancer, lung cancer, } \\
\text { liver cancer,etc. }\end{array}$ & \\
\hline & & & 3 Mastoparan & 3 Peptide (14aa) & 3 Pancreatic cancer cells & \\
\hline & & Phospholipids & Hemilipin & heterodime & HUVECs and HPAECs & Preclinical studies \\
\hline
\end{tabular}

Most snake venoms are a mixture of several proteins, peptides, toxins, enzymes and non-protein components. ${ }^{82}$ Bioactive peptides from snake venoms have significantly contributed to the treatment of many humandiseases, and some of them may selectively target cancer cell membranes, affecting the proliferation of cancer cells. ${ }^{83}$ For example, crotamine, a polypeptide of 42 amino acids isolated from South American rattle snake venom; cathelicidin-BF (BF-30) is a cathelicidin-like polypeptide of 30 amino acids and a natural antibacterial peptide extracted from the venom of the snake Bungarus fasciatus; purified L-amino acid oxidases from Bothrops leucurus which is toxic to cancer cell. ${ }^{84}$

\section{CONCLUSION}

This review aims to boost the use of natural product arising from their anticancer activities. Natural product proven to have efficacy asan anticancer activity already. The mechanism of action of many products has been identified and other still under investigation. Overall, natural product research is a vigorous tool to discover novel biologically active components with unique mechanisms of action. Given the diversity of nature, it is sensible to indicate that chemical leads can be produced that are able to interact with most therapeutic targets. As such, new and efficacious drugs can be developed by way of safety treatment of the cancer diseases and get rid of it.

\section{CONFLICT OF INTEREST |}

The authors declare that they have no conflicts of interest

\section{REFERENCES |}

1. Mangal M, Sagar P, Singh H, Raghava GP, Agarwal SM. NPACT: Naturally occurring plant-based anti-cancer compound-activitytarget database. Nucleic Acids Res. 2012; 41: D1124-D1129. doi: $10.1093 / \mathrm{nar} / \mathrm{gks} 1047$

2. Balunas MJ, Kinghorn AD. Drug discovery from medicinal plants. Life Sci. 2005; 78: 431-441. doi: 10.1016/j.lfs.2005.09.012

3. Newman DJ, Cragg GM. Natural products as sources of new drugs over the last 25 years. J Nat Prod. 2007; 70: 461-477. doi: $10.1021 / \mathrm{np} 068054 \mathrm{v}$

4. David B, Wolfender JL, Dias DA. The pharmaceutical industry and natural products: Historical status and new trends. Phytochemistry Reviews. 2015; 14: 299-315. doi: 10.1007/s1110

5. Kinghorn AD, Chin YW, Swanson SM. Discovery of natural product anticancer agents from biodiverse organisms. Curr Opin Drug Discov Devel. 2009; 12: 189-196.

6. Goldman A, Kulkarni A, Sengupta S. Methods and compo- 
sitions relating to the treatment of cancer. Google Patents. Web site. https://patentimages.storage.googleapis.com/ef/ da/6d/3ae68471b194c8/WO2016033472A1.pdf. 2015. Accessed July 14, 2019.

7. Tan G, Gyllenhaal C, Soejarto D. Biodiversity as a source of anticancer drugs. Curr Drug Targets. 2006; 7: 265-277. doi: $10.2174 / 138945006776054942$

8. Cragg GM, Katz F, Newman DJ, Rosenthal J. The impact of the United Nations convention on biological diversity on natural products research. Nat Prod Rep. 2012; 29: 1407-1423. doi: $10.1039 / \mathrm{c} 2 \mathrm{np} 20091 \mathrm{k}$

9. Berdy J. Bioactive microbial metabolites. I Antibiot (Tokyo). 2005; 58: 1-26. doi: 10.1038/ja.2005.1

10. Krause J, Tobin G. Discovery, development, and regulation of natural products. In: Kulka M, ed. Using Old Solutions to New Problems-Natural Drug Discovery in the $21^{\text {st }}$ Century. London, United Kingdom: IntechOpen; 2013: 3-35. doi: 10.5772/56424

11. Phifer SS, Lee D, Seo EK, et al. Alvaradoins E-N, antitumor and cytotoxic anthracenone C-glycosides from the leaves of alvaradoa haitiensis. J Nat Prod. 2007; 70: 954-961. doi: 10.1021/ np070005a

12. Shnyder SD, Cooper PA, Millington NJ, Gill JH, Bibby MC. Sodium pancratistatin 3, 4-o-cyclic phosphate, a water-soluble synthetic derivative of pancratistatin, is highly effective in a human colon tumor model. J Nat Prod. 2007; 71: 321-324. doi: 10.1021/np070477p

13. Winkel-Shirley B. Flavonoid biosynthesis. A colorful model for genetics, biochemistry, cell biology, and biotechnology. Plant Physiol. 2001; 126: 485-493. doi: 10.1104/pp.126.2.485

14. Li H, Wang Z, Liu Y. Review in the studies on tannins activity of cancer prevention and anticancer. Zhong Yao Cai. 2003; 26: 444-448.

15. Aggarwal BB, Kumar A, Bharti AC. Anticancer potential of curcumin: preclinical and clinical studies. Anticancer Res. 2003; 23: 363-398.

16. Udenigwe CC, Ramprasath VR, Aluko RE, Jones PJ. Potential of resveratrol in anticancer and anti-inflammatory therapy. Nutr Rev. 2008; 66: 445-454. doi: 10.1111/j.1753-4887.2008.00076.x

17. Greenwell M, Rahman P. Medicinal plants: Their use in anticancer treatment. Int J Pharm Sci Res. 2015; 6: 4103-4112. doi: 10.13040/IJPSR.0975-8232.6(10)

18. Prakash O, Kumar A, Kumar P, Ajeet A. Anticancer potential of plants and natural products: A review. American Journal of Pharmacological Sciences. 2013; 1: 104-115. doi: 10.12691/ajps-1-6-1
19. Boopathy NS, Kathiresan K. Anticancer drugs from marine flora: An overview. Journal of oncology. 2010; 2010: 214186. doi: $10.1155 / 2010 / 214186$

20. Rothschild LJ, Mancinelli RL. Life in extreme environments. Nature. 2001; 409: 1092-1101. doi: 10.1038/35059215

21. Sarfaraj HM, Sheeba F, Saba A, Khan M. Marine natural products: A lead for Anti-cancer. Indian Journal of Geo-Marine Sciences. 2012; 41(1): 27-39.

22. Kalimuthu S, Se-Kwon K. Cell survival and apoptosis signaling as therapeutic target for cancer: Marine bioactive compounds. Int J Mol Sci. 2013; 14: 2334-2354. doi: 10.3390/ijms14022334

23. Haefner B. Drugs from the deep: Marine natural products as drug candidates. Drug Discov Today. 2003; 8: 536-544. doi: 10.1016/S1359-6446(03)02713-2

24. Jha R, Zi-Rong X. Biomedical compounds from marine organisms. Mar Drugs. 2004; 2: 123-146. doi: 10.3390/md203123

25. Bull AT, Stach JE. Marine actinobacteria: New opportunities for natural product search and discovery. Trends Microbiol. 2007; 15: 491-499. doi: 10.1016/j.tim.2007.10.004

26. Soria-Mercado IE, Villarreal-Gómez LJ, Rivas GG, Sánchez NEA. Bioactive compounds from bacteria associated to marine algae. In: Sammour R, ed. Biotechnology-Molecular Studies and Novel Applications for Improved Quality of Human Life Croatia. London, United Kingdom: IntechOpen; 2012: 25-44. doi: 10.5772/27842

27. James A. Potential of bioactive compounds from marine actinomycetes against extended specturem of beta lactamase roducing pathogens and cancer cell lines hct 116 and hep g2 an in vitro study. 2016.

28. Amador ML, Jimeno J, Paz-Ares L, Cortes-Funes H, Hidalgo M. Progress in the development and acquisition of anticancer agents from marine sources. Anna Oncol. 2003; 14: 1607-1615. doi: $10.1093 /$ annonc/mdg443

29. Bugni TS, Ireland CM. Marine-derived fungi: A chemically and biologically diverse group of microorganisms. Nat Prod Rep. 2004; 21: 143-163. doi: 10.1039/b301926h

30. Raghukumar C. Marine fungal biotechnology: An ecological perspective. Fungal diversity. 2008; 13: 19-35.

31. Thajuddin N, Subramanian G. Cyanobacterial biodiversity and potential applications in biotechnology. Current science. 2005; 89: 47-57.

32. Varshney A, Singh V. Effects of algal compounds on cancer cell line. J Exp Biol. 2013; 1: 337-352.

33. Costa M, Garcia M, Costa-Rodrigues J, et al. Exploring bioac- 
tive properties of marine cyanobacteria isolated from the Portuguese coast: high potential as a source of anticancer compounds. Mar Drugs. 2013; 12: 98-114. doi: 10.3390/md12010098

34. Gerwick WH, Proteau PJ, Nagle DG, Hamel E, Blokhin A, Slate DL. Structure of curacin A, a novel antimitotic, antiproliferative and brine shrimp toxic natural product from the marine cyanobacterium Lyngbya majuscula. The Journal of organic chemistry. 1994; 59: 1243-1245. doi: 10.1021/jo00085a006

35. Kumar CS, Ganesan P, Suresh P, Bhaskar N. Seaweeds as a source of nutritionally beneficial compounds-a review. Journal of Food Science and Technology. 2008; 45: 1-13.

36. Zakaria NA, Ibrahim D, Sulaiman SF, Supardy A. Assessment of antioxidant activity, total phenolic content and in-vitro toxicity of Malaysian red seaweed, Acanthophora spicifera. J Chem Pharm Res. 2011; 3: 182-191.

37. Lavakumar V, Ahamed K, Ravichandran V. Anticancer and antioxidant effect of Acanthophora spicifera against EAC induced carcinoma in mice. Journal of Pharmacy Research. 2012; 5: 1503-1507.

38. Lee JC, Hou MF, Huang HW, et al. Marine algal natural products with anti-oxidative, anti-inflammatory, and anti-cancer properties. Cancer Cell Int. 2013; 13: 55. doi: 10.1186/1475-2867-13-55

39. Ayyad S-EN, Ezmirly ST, Basaif SA, Alarif WM, Badria AF, Badria FA. Antioxidant, cytotoxic, antitumor, and protective DNA damage metabolites from the red sea brown alga Sargassum sp. Pharmacognosy Res. 2011; 3: 160-165. doi: 10.4103/09748490.85000

40. Zhuang $\mathrm{C}$, Itoh $\mathrm{H}$, Mizuno T, Ito $\mathrm{H}$. Antitumor active fucoidan from the brown seaweed, umitoranoo (Sargassum thunbergii). Biosci Biotechnol Biochem. 1995; 59: 563-567. doi: 10.1271/ bbb. 59.563

41. Jiang Z, Okimura T, Yokose T, Yamasaki Y, Yamaguchi K Oda T. Effects of sulfated fucan, ascophyllan, from the brown Alga Ascophyllum nodosum on various cell lines: A comparative study on ascophyllan and fucoidan. J Biosci Bioeng. 2010; 110: 113117. doi: $10.1016 /$ j.jbiosc.2010.01.007

42. Vijayakumar S, Menakha M. Pharmaceutical applications of cyanobacteria-A review. Journal of Acute Medicine. 2015; 5: 15-23. doi: 10.1016/j.jacme.2015.02.004

43. Dhorajiya B, Malani M, Dholakiya B. Extraction and preservation protocol of anti-cancer agents from marine world. Chemical Sciences Journal. 2012; 2012: 1-12.

44. Manilal A, Sujith S, Kiran GS, et al. Biopotentials of seaweeds collected from southwest coast of India. Journal of Marine Science and Technology. 2009; 17: 67-73.
45. Shibata T, Fujimoto K, Nagayama K, Yamaguchi K, Nakamura T. Inhibitory activity of brown algal phlorotannins against hyaluronidase. International journal of food science \& technology. 2002; 37: 703-709. doi: 10.1046/j.1365-2621.2002.00603.x

46. Amer ME, Abou-Shoer MI, Abdel-Kader MS, El-Shaibany A, Abdel-Salam NA. Alkaloids and flavone acyl glycosides from Acanthus arboreus. Journal of the Brazilian Chemical Society. 2004; 15: 262-266. doi: 10.1590/S0103-50532004000200016

47. Uzma F, Mohan CD, Hashem A, et al. Endophytic fungi-alternative sources of cytotoxic compounds: A review. Front Pharmacol. 2018; 9: 309. doi: 10.3389/fphar.2018.00309

48. Peakman M, Vergani D. Basic and Clinical Immunology E-Book: with STUDENT CONSULT Access. London, UK: Churchill Livingstone; 2009.

49. Doll R, Peto R. The causes of cancer: Quantitative estimates of avoidable risks of cancer in the United States today. $J$ Natl Cancer Inst. 1981; 66: 1192-1308.

50. Forbes NS. Engineering the perfect (bacterial) cancer therapy. Nat Rev Cancer. 2010; 10: 785-794. doi: 10.1038/nrc2934

51. Cragg GM, Newman DJ. Antineoplastic agents from natural sources: Achievements and future directions. Expert Opin Investig Drugs. 2000; 9: 2783-2797. doi: 10.1517/13543784.9.12.2783

52. Szakács G, Paterson JK, Ludwig JA, Booth-Genthe C, Gottesman MM. Targeting multidrug resistance in cancer. Nat Rev Drug Discov. 2006; 5: 219-234. doi: 10.1038/nrd1984

53. Yang W. Fast Viability Assessment of Clostridium Spores: Survival in Extreme environments. [dissertation]. CA, USA: California Institute of Technology; 2010.

54. Cheesbrough M. District Laboratory Practice in Tropical Countries. Cambridge, England, UK: Cambridge University Press; 2006.

55. Herr HW, Morales A. History of bacillus Calmette-Guerin and bladder cancer: An immunotherapy success story. J Urol. 2008; 179: 53-56. doi: 10.1016/j.juro.2007.08.122

56. Ogita S, Tsuto T, Nakamura K, Deguchi E, Tokiwa K, Iwai N. OK-432 therapy for lymphangioma in children: Why and how does it work? J Pediatr Surg. 1996; 31: 477-480. doi: 10.1016/ s0022-3468(96)90478-9

57. Roberts NJ, Zhang L, Janku F, et al. Intratumoral injection of clostridium novyi-NT spores induces antitumor responses. Sci Transl Med. 2014; 6: 249ra111. doi: 10.1126/scitranslmed.3008982

58. Wei MQ, Ellem KA, Dunn P, West MJ, Bai CX, Vogelstein B. Facultative or obligate anaerobic bacteria have the potential for multimodality therapy of solid tumours. Eur J Cancer. 2007; 43: 490-496. doi: 10.1016/j.ejca.2006.10.005 
59. Hurst LC, Badalamente MA, Hentz VR, et al. Injectable collagenase clostridium histolyticum for Dupuytren's contracture. $N$ Engl J Med. 2009; 361: 968-979. doi: 10.1056/NEJMoa0810866

60. Lukasiewicz K, Fol M. Microorganisms in the treatment of cancer: Advantages and limitations. Journal of Immunology Research. 2018; 2018. 1-8. doi: 10.1155/2018/2397808

61. Zhou P, Chen Z, Li H-L, et al. Toxoplasma gondii infection in humans in China. Parasit Vectors. 2011; 4: 165. doi: 10.1186/17563305-4-165

62. Karamati SA, Hassanzadazar H, Bahmani M, Rafieian Kopaei M. Herbal and chemical drugs effective on malaria. Asian Pacific Journal of Tropical Disease. 2014; 4: S599-S601. doi: 10.1016/ S2222-1808(14)60686-1

63. Roos MA, Gennero L, Denysenko T, et al. Microparticles in physiological and in pathological conditions. Cell Biochem Funct. 2010; 28: 539-548. doi: 10.1002/cbf.1695

64. Ryan JT, Ross RP, Bolton D, Fitzgerald GF, Stanton C. Bioactive peptides from muscle sources: Meat and fish. Nutrients. 2011; 3: 765-791. doi: 10.3390/nu3090765

65. Möller NP, Scholz-Ahrens KE, Roos N, Schrezenmeir J. Bioactive peptides and proteins from foods: Indication for health effects. Eur J Nutr. 2008; 47: 171-182. doi: 10.1007/s00394-0080710-2

66. Qi F, Li A, Inagaki Y, et al. Antitumor activity of extracts and compounds from the skin of the toad Bufo bufo gargarizans Cantor. Int Immunopharmacol. 2011; 11: 342-349. doi: 10.1016/j. intimp.2010.12.007

67. Conlon JM, Demandt A, Nielsen PF, Leprince J, Vaudry H, Woodhams DC. The alyteserins: Two families of antimicrobial peptides from the skin secretions of the midwife toad Alytes obstetricans (Alytidae). Peptides. 2009; 30: 1069-1073. doi: 10.1016/j. peptides.2009.03.004

68. Conlon JM. Structural diversity and species distribution of host-defense peptides in frog skin secretions. Cell Mol Life Sci. 2011; 68: 2303-2315. doi: 10.1007/s00018-011-0720-8

69. Rozek T, Bowie JH, Wallace JC, Tyler MJ. The antibiotic and anticancer active aurein peptides from the Australian bell frogs litoria aurea and litoria raniformis. Part 2. Sequence determination using electrospray mass spectrometry. Rapid Commun Mass Spectrom. 2000; 14: 20022011. doi: 10.1002/1097-0231(20001115)14:21<2002::AIDRCM128>3.0.CO;2-3

70. van Zoggel H, Hamma-Kourbali Y, Galanth C, et al. Antitumor and angiostatic peptides from frog skin secretions. Amino Acids. 2012; 42: 385-395. doi: 10.1007/s00726-010-0815-9
71. Abdel-Wahab YHA, Power GJ, Flatt PR, Woodhams DC, Rollins-Smith LA, Conlon JM. A peptide of the phylloseptin family from the skin of the frog Hylomantis lemur (Phyllomedusinae) with potent in vitro and in vivo insulin-releasing activity. Peptides. 2008; 29: 2136-2143. doi: 10.1016/j.peptides.2008.09.006

72. Theansungnoen T, Maijaroen S, Jangpromma N, et al. Cationic antimicrobial peptides derived from crocodylus siamensis leukocyte extract, revealing anticancer activity and apoptotic induction on human cervical cancer cells. Protein J. 2016; 35: $202-$ 211. doi: $10.1007 /$ s10930-016-9662-1

73. He S, Mao X, Zhang T, et al. Separation and nanoencapsulation of antitumor peptides from Chinese three-striped box turtle (Cuora trifasciata). J Microencapsul. 2016; 33: 344-354. doi: 10.1080/02652048.2016.1194904

74. Aneiros A, Garateix A. Bioactive peptides from marine sources: Pharmacological properties and isolation procedures. $J$ Chromatogr B Analyt Technol Biomed Life Sci. 2004; 803: 41-53. doi: 10.1016/j.jchromb.2003.11.005

75. Goudet C, Chi CW, Tytgat J. An overview of toxins and genes from the venom of the Asian scorpion Buthus martensi Karsch. Toxicon. 2002; 40: 1239-1258.

76. Mamelak AN, Jacoby DB. Targeted delivery of antitumoral therapy to glioma and other malignancies with synthetic chlorotoxin (TM-601). Expert Opin Drug Deliv. 2007; 4: 175-186. doi: 10.1517/17425247.4.2.175

77. King GF, Hardy MC. Spider-venom peptides: Structure, pharmacology, and potential for control of insect pests. Annu Rev Entomol. 2013; 58: 475-496. doi: 10.1146/annurev-ento-120811-153650

78. Vorontsova OV, Egorova NS, Arseniev AS, Feofanov AV. Haemolytic and cytotoxic action of latarcin Ltc2a. Biochimie. 2011; 93: 227-241. doi: 10.1016/j.biochi.2010.09.016

79. Moreno M, Giralt E. Three valuable peptides from bee and wasp venoms for therapeutic and biotechnological use: Melittin, apamin and mastoparan. Toxins (Basel). 2015; 7: 1126-1150. doi: $10.3390 /$ toxins 7041126

80. Gajski G, Garaj-Vrhovac V. Melittin: A lytic peptide with anticancer properties. Environ Toxicol Pharmacol. 2013; 36: 697-705. doi: 10.1016/j.etap.2013.06.009

81. de Azevedo RA, Figueiredo CR, Ferreira AK, et al. Mastoparan induces apoptosis in B16F10-Nex2 melanoma cells via the intrinsic mitochondrial pathway and displays antitumor activity in vivo. Peptides. 2015; 68: 113-119. doi: 10.1016/j.peptides.2014.09.024

82. Vyas VK, Brahmbhatt K, Bhatt H, Parmar U. Therapeutic potential of snake venom in cancer therapy: Current perspectives. Asian Pac J Trop Biomed. 2013; 3: 156-162. doi: 10.1016/S2221- 
1691(13)60042-8

83. Calderon LA, Sobrinho JC, Zaqueo KD, et al. Antitumoral activity of snake venom proteins: New trends in cancer therapy. Biomed Res Int. 2014; 2014: 203639. doi: 10.1155/2014/203639

84. Rádis-Baptista G, Oguiura N, Hayashi MAF, et al. Nucleotide sequence of crotamine isoform precursors from a single South American rattlesnake (Crotalus durissus terrificus). Toxicon. 1999; 37: 973-984.

85. Ma R, Mahadevappa R, Kwok HF. Venom-based peptide therapy: Insights into anti-cancer mechanism. Oncotarget. 2017; 8: 100908-100930. doi: 10.18632/oncotarget.21740 